\title{
Effect of water temperature on individual reproductive activity of pollack (Pollachius pollachius)
}

\author{
M. Suquet ${ }^{a, *}$, Y. Normant ${ }^{a}$, J.L. Gaignon ${ }^{a}$, L. Quéméner $^{a}$ and C. Fauvel ${ }^{b}$ \\ a Ifremer, Laboratoire ARN, BP 70, Plouzané 29280, France \\ ${ }^{b}$ Ifremer, Chemin de Maguelone, Palavas 34250, France \\ *: Corresponding author : Tel..33 2982243 94, fax: 332982243 66, mail: msuquet@ifremer.fr
}

\begin{abstract}
:
The effects of water temperature on pollack (Pollachius pollachius) spawning features were individually assessed. During the spawning period, nine fish sets, each composed of one female and two males (mean body weight: $2.5 \pm 1.0 \mathrm{~kg}$ ), were placed in small-volume tanks $(2 \mathrm{~m} 3)$. Fish sets were held at 8,10 , or $12^{\circ} \mathrm{C}(\mathrm{n}=3$ for each temperature).

Three females released eggs at 8 and $10^{\circ} \mathrm{C}$, while only two spawned at $12{ }^{\circ} \mathrm{C}$. One hundred thirtyone individual spawns were collected from the eight spawning fish sets. The number of spawns collected per female was significantly lower at $12{ }^{\circ} \mathrm{C}(3.0 \pm 3.6)$, compared to $10^{\circ} \mathrm{C}(17.3 \pm 10.1)$ and 8 ${ }^{\circ} \mathrm{C}(23.3 \pm 2.5)$. Egg number (eggs $\mathrm{kg}-1 \mathrm{BW}$ ) was significantly lowered at $12{ }^{\circ} \mathrm{C}(26,068 \pm 35,989)$ compared to $10^{\circ} \mathrm{C}(323,230 \pm 136,796)$ and $8^{\circ} \mathrm{C}(599,612 \pm 249,545)$. The number of viable eggs (eggs $\mathrm{kg}-1 \mathrm{BW})$ was significantly lower at $12{ }^{\circ} \mathrm{C}(4,175 \pm 7,167)$ compared to $8{ }^{\circ} \mathrm{C}(192,034 \pm 145,870)$.

When incubated at a common temperature of $10^{\circ} \mathrm{C}$, hatching and malformation percentages were significantly enhanced for breeders maintained at $8{ }^{\circ} \mathrm{C}$ (respectively, $35.8 \pm 8.5-7.3 \pm 1.4 \%$ ) compared to $10{ }^{\circ} \mathrm{C}(9.8 \pm 8.0-2.3 \pm 1.8 \%)$. Then, pooling data were recorded at the three temperatures; a significant decrease of egg diameter with time was observed.

The individual reproductive activity of pollack experienced by breeders was deeply affected by temperature during the spawning period. A temperature of $12{ }^{\circ} \mathrm{C}$ is suggested to be close to the temperature reproduction upper limit in this species.
\end{abstract}

Keywords: Gadoids; Pollack; Pollachius pollachius; Reproduction; Temperature; Egg quality 


\section{1) Introduction}

The candidature of pollack for the development of temperate finfish aquaculture is sustained by its rapid growth (600g for 2-year-old animals) compared to presently reared species such as seabass (Dicentrarchus labrax) or seabream (parus aurata), its ability to water temperature conditions of Northern coasts of France, its high flesh quality and the availability of wild fish for broodstock (Suquet, 2001; Buchet et al., 2002).

In captivity, first maturity was observed in 2 year old males $(0.7 \mathrm{~kg})$ and 3 year old females $(1.1 \mathrm{~kg})$. Reproductive cycle of pollack was described in terms of steroids concentration and oocyte development (Omnes et al., 2002). Spontaneous spawning in captivity has been reported for pollack broodstock held in $15 \mathrm{~m}^{3}$ tanks for temperature ranging from 9.5 to $11.8^{\circ} \mathrm{C}$ (Suquet et al., 1996). Pollack is a batch spawner (mean: 5 batches per female from January to April), having a high fecundity (close to 600,000 eggs. $\mathrm{kg}^{-1}$ ). However, large variations of egg quality were recorded (Omnes et al., 2002).

In the literature, egg output of different fish species is mainly recorded from groups of breeders, but these estimates do not provide information on individual variations in egg batch production, quantity and quality of egg released. Egg production of adult pairs of Atlantic cod (Gadus morhua) and haddock (Melanogramus aeglefinus) were monitored over the spawning period and showed high variability among individuals (Trippel et al., 2000; Ouellet et al., 2001). In order to estimate this variation, individual performances of pollack breeders were recorded in this work.

Fish reproduction is highly sensitive to water temperature (Van der Kraak and Pankhurst, 1996). Temperature may modulate hormone action at all levels of the reproductive endocrine system, affecting the different phases of fish reproduction and 
especially ovulation and spawning. Mathematical modelling demonstrates a significant correlation between water temperature and recruitment of cod stocks (Poertner et al., 2001). Brander (1996) stated that about $28 \%$ of the variability observed in Northeast Arctic cod recruitment was probably due to changes in water temperature. On the other hand from 1919 to 1994, fluctuations in cod and pollack along the Norwegian Skagerrak coast were related neither to the North Atlantic Oscillation nor to sea surface temperature (Fromentin et al., 1998). However, these authors used temperature values recorded in winter (from December to March) before the spawning period of pollack. Furthermore Skagerrak populations of cod and pollack being in the middle of their distributions, they suggested that the effect of temperature changes could be less important than for populations which are closed to their geographical boundaries. In captivity, fertilization and hatching rates of Atlantic halibut (ipppoglossus hippoglossus) eggs decreased when water temperature exceeded $8^{\circ} \mathrm{C}$ (Brown et al., 1995). Ovulation of common wolffish (Anarhichas lupus) was delayed at 8 and $12^{\circ} \mathrm{C}$, compared to $4^{\circ} \mathrm{C}$ and the survival of eggs incubated at a common temperature of $6^{\circ} \mathrm{C}$, was significantly decreased for breeders exposed at $12^{\circ} \mathrm{C}$ (Tveiten et al., 2001). Increasing temperature from $8^{\circ} \mathrm{C}$ to $12^{\circ} \mathrm{C}$ decreased the percentage of ovulating cod females (Johansen et al., 1999) while in the same species, the fertilization percentage decreased when water temperature was higher than $10^{\circ} \mathrm{C}$ (Van der Meeren and Ivannikov, 2001).

In the wild, pollack reproduction is observed from a temperature of $10^{\circ} \mathrm{C}$ (Quéro and Vayne, 1997) but the range is not reported in the literature. However, the effect of water temperature on the reproductive activity of pollack is not yet reported in the literature. The present study provides information on this topic both required for rearing but also for a better comprehension of recruitment mechanisms in this species. 


\section{2) Material and methods}

\subsection{Broodstock}

Pollack caught in the wild were maintained for three years in $15 \mathrm{~m}^{3}$ (surface: $15 \mathrm{~m}^{2}$ ) outdoor circular tanks and exposed to natural variations of daylength (from 8h30L:15h30D to $16 \mathrm{hL}: 8 \mathrm{hD})$ and temperature $\left(8-17^{\circ} \mathrm{C}\right)$. They were fed ad libitum twice

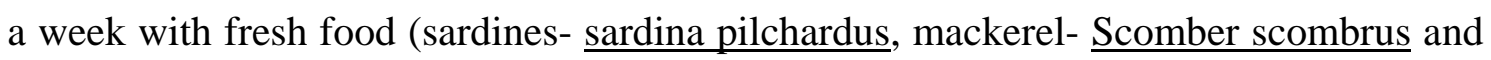

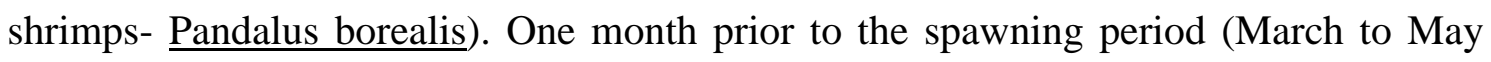
2002), oocyte development was monitored weekly by biopsy, after fish anaesthesia in Ethylene glycol monophenylether (200 ppm). The diameter of the largest 30 oocytes was recorded. When mean oocyte diameter reached $650 \mu \mathrm{m}$, females were considered ripe and transferred to the experimental tanks for temperature manipulation.

\subsection{Experimental design}

Experimental facilities were composed of nine indoor $2 \mathrm{~m}^{3}$ (surface $4 \mathrm{~m}^{2}$ ) tanks. Nine fish sets, each composed of one female and two males (mean body weight: $2.5 \pm 1.0 \mathrm{~kg}$ ), were randomly placed in the experimental tanks. Fish were held during the spawning period at $8^{\circ} \mathrm{C}, 10^{\circ} \mathrm{C}$ or $12^{\circ} \mathrm{C}$ ( $\mathrm{n}=3$ for each temperature). Only males having milt showing motility higher than $50 \%$ motile spermatozoa (dilution sperm:seawater 1:100) were selected. Fish were exposed to the natural variations of daylength and seawater renewal was 30\% tank volume.hour ${ }^{-1}$. Tanks were fitted with $40 \mathrm{l}$ devices that collected all released eggs from both the surface and the drain. Collectors were examined daily. 
For each spawn, egg number and fertilization percentage were assessed through a dissecting microscope from three $15 \mathrm{ml}$ samples. Eggs were considered viable when 2 blastomeres or more were observed. Fertilization percentage [(the number of viable eggs/the total number of eggs)*100] was calculated.

For each batch having a fertilization percentage higher than $10 \%$, the diameters of 30 viable eggs were recorded. Then, duplicate batches of 500 eggs were transferred into 1-L cylindroconical tanks and incubated at a common temperature of $10^{\circ} \mathrm{C}$. A $300 \%$ water renewal per hour was added. Dead eggs were collected daily from the bottom of each incubator by sampling $150 \mathrm{ml}$ water and then counting eggs. Hatching was observed after 7 days. The total number of viable larvae and non viable larvae (dead and malformed: V shaped larvae) was counted. Hatching percentage [(number of larvae/total number of eggs transferred to incubators)*100] and malformation percentage [(number of non viable larvae/total number of larvae)*100] were recorded.

At the beginning of the experiment, the prespawning condition factor of females [Kpre: (body weight/length $\left.{ }^{3}{ }^{*} 100\right]$ was calculated. Then at the end of the experiment, the postspawning (Kpost) condition factor of each female was determined. Furthermore, $\underline{K}$ losses of females ( $\underline{K} L)$ were calculated according to the following formula:

$$
\underline{\text { KL }}(\%)=[(\underline{\text { Kpre}}-\underline{\text { Kpost}}) / \underline{\text { Kpre }}]^{* 100} \text {. }
$$




\subsection{Statistical analysis}

Data were expressed as mean \pm SD. Egg counts were subjected to square root transformation and fertilization, hatching and malformation percentages to angular transformation. Data were compared using a one-way ANOVA. When the differences were significant $(\underline{\mathrm{P}<0.05)})$ a Newman-Keuls a posteriori test was used for comparison purposes. Then, pooling performances recorded in all females, changes in oocyte diameter but also fertilization, hatching and malformation percentages with time were evaluated by linear regression for transformed data.

\section{3) Results}

At the beginning of the experiment, the mean length $(59.1 \pm 3.4 \mathrm{~cm})$, the mean weight $(3.0 \pm 0.5 \mathrm{~kg})$ and the mean prespawning condition factor (Kpre:1.43 \pm 0.10$)$ of females did not show any significant differences between the three groups of fish subjected to the different temperatures. One hundred and thirty one individual spontaneous spawns were collected from the nine $2 \mathrm{~m}^{3}$ experimental tanks. Three females released eggs at 8 and $10^{\circ} \mathrm{C}$, compared to two females at $12^{\circ} \mathrm{C}$. The number of days recorded between the observation of a $650 \mu$ mean oocyte diameter and the first collection of egg batch was not significantly different between the three temperatures (3.2 \pm 3.3 days). On the other hand, the duration of spawning period was significantly higher at $8^{\circ} \mathrm{C}$, compared to 10 and $12^{\circ} \mathrm{C}$ (Table 1). Furthermore, the number of spawns collected per female was significantly lower at $12^{\circ} \mathrm{C}$, compared to 8 and $10^{\circ} \mathrm{C}$ (Table 1 ). The interval between two consecutive egg batches (8.6 \pm 14.8 days) was not significantly different between the groups. 
The number of eggs collected was very variable and it generally decreased at the end of the spawning period (Fig.1). A significantly lower total egg number per kg B.W. was observed at $12^{\circ} \mathrm{C}$, compared to $8^{\circ} \mathrm{C}$ and $10^{\circ} \mathrm{C}$ (Table 1). Furthermore, the number of viable eggs per $\mathrm{kg} \mathrm{B}$.W. was significantly lower at $12^{\circ} \mathrm{C}$ compared to $8^{\circ} \mathrm{C}$ but not to $10^{\circ} \mathrm{C}$. Fertilization percentages were not significantly different between the three temperatures.

The hatching and the malformation percentages were significantly higher at $8^{\circ} \mathrm{C}$ compared to $10^{\circ} \mathrm{C}$ (Table 1). Egg diameter was not significantly different between the three temperatures $(1184 \pm 54 \mu \mathrm{m})$. The postspawning condition factor ( $\underline{\text { ppost}}=1.15 \pm 0.09)$ and $\underline{\mathrm{K}}$ losses $(\underline{\mathrm{K}} \mathrm{L}=18.8 \pm 7.4)$ were not significantly different among the three groups of fish.

When pooling data recorded from the nine females, the total egg number released per female was significantly related to the decrease of the condition factor (Kpre-Kpost) (Fig.2). Furthermore, a significant decrease of viable egg diameter with time was observed (Fig.3). On the other hand, no significant changes of fertilization, hatching and malformation percentages with time were observed.

\section{DISCUSSION}

Information on individual reproductive activity in fish species is rarely reported in the litterature since it requires well adapted facilities to be performed. Furthermore, this experimental design is time consuming because each spawn is managed individually in terms of number of eggs, fertilization percentage, hatching percentage and larval deformities and especially in batch spawner fish species such as pollack.

A small tank volume may prevent the reproductive activity of some fish species. For instance, seabass females did not spawn spontaneously in $2 \mathrm{~m}^{3}$ tanks (Fornies et al., 
2001). On the other hand, cod eggs were collected in 1.2 and $3.5 \mathrm{~m}^{3}$ tanks (Trippel, 1998; Trippel et al., 2000; Ouellet et al., 2001). In this work, one hundred and thirty one spontaneous spawns of pollack were collected in small volume tanks $\left(2 \mathrm{~m}^{3}\right)$. Fecundity observed in $2 \mathrm{~m}^{3}$ tanks was closed to that reported in a $15 \mathrm{~m}^{3}$ tank (Suquet et al., 1996), indicating a good adaptation of pollack to these small volumes.

Fish species ovulate over a limited temperature range. This temperature "window” was suggested to be conducive to larval survival (Bye, 1984). Increasing water temperature from 8 to $12^{\circ} \mathrm{C}$ decreased the number of ovulating female pollack. A similar decrease is reported in other fish species: the percentage of ovulating rainbow trout (Oncorhynchus mykiss) decreased above $15^{\circ} \mathrm{C}$ (Pankhurst et al., 1996). 57\% of Atlantic salmon ( $\underline{\text { Salmo salar }}$ ) ovulated at $13-14^{\circ} \mathrm{C}$, compared to $98 \%$ at $5-7^{\circ} \mathrm{C}$ (Taranger and Hansen, 1993). In cod, the percentage of ovulating females was higher at $8^{\circ} \mathrm{C}(89 \%)$, than at $12^{\circ} \mathrm{C}(75 \%)$ and at $15^{\circ} \mathrm{C}(77 \%)$ (Johansen et al., 1999). However, this result was observed in Northeast Arctic cod but not in coastal cod, reflecting different requirements to environmental conditions between strains. Seabass failed to spawn spontaneously unless water temperature was reduced below $16^{\circ} \mathrm{C}$ (Carillo et al., 1993). In these different species, it was suggested that ovulation could be altered or prevented under temperature conditions detrimental to gamete survival.

The spring spawning grounds of pollack extend from Norway to Portugal at depths ranging from 0 to $150 \mathrm{~m}$ (Quéro and Vayne, 1997) which encompass a temperature range of $9-13^{\circ} \mathrm{C}$ during the spawning period (Maillard, 1986; Levitus and Boyer, 1994). These values are in the same range of those used in the present work..

Increasing temperature from $8^{\circ} \mathrm{C}$ to $12^{\circ} \mathrm{C}$ had a negative impact on pollack spawning performance since it significantly decreased the total number of eggs by $96 \%$ and the number of viable eggs by $98 \%$. Compared to temperatures of $5-7^{\circ} \mathrm{C}$, a 33 to 
$40 \%$ decrease of total egg production was reported in Atlantic halibut maintained at temperatures ranging from 4 to $11^{\circ} \mathrm{C}$ (Brown et al., 1995). Egg production of rainbow trout was similar between 9 and $15^{\circ} \mathrm{C}$ but significantly decreased at $18^{\circ} \mathrm{C}$ and $21^{\circ} \mathrm{C}$ (Pankhurst et al., 1996). In this species, the decrease of egg production and the observation of atretic oocytes suggest a partial ovulation, associated with elevated temperatures.

The fertilization percentage of pollack eggs was not significantly affected by water temperature in the range of 8 to $12^{\circ} \mathrm{C}$. According to these results, the fertilization rates of wolffish eggs were not significantly different between groups of females maintained at 4,8 or $12^{\circ} \mathrm{C}$ throughout the spawning season (Tveiten et al., 2001). When incubated at a common temperature of $10^{\circ} \mathrm{C}$, a higher hatching percentage and malformation percentage of pollack larvae were observed when breeders were kept at $8^{\circ} \mathrm{C}$ compared to $10^{\circ} \mathrm{C}$ which resulted in a higher production of good quality larvae at $8^{\circ} \mathrm{C}$. Compared to $6^{\circ} \mathrm{C}$, the hatching rate of Atlantic halibut eggs was lowered when breeders were maintained at water temperature exceeding $8^{\circ} \mathrm{C}$ (Brown et al., 1995). A 30 to $50 \%$ reduction of fertilization percentage and an increase in deformities percentage was reported in cod when water temperature exceeded $10^{\circ} \mathrm{C}$ in the spawning tank (Van der Meeren and Ivannikov, 2001). When incubated at a common temperature of $11^{\circ} \mathrm{C}$, egg survival to the eyed stage was significantly lower in rainbow trout breeders subjected to 18 and $21^{\circ} \mathrm{C}$ than results observed for fish kept at 9,12 and $15^{\circ} \mathrm{C}$ (Pankhurst et al., 1996). In pollack as in these different fish species, these observations show that temperature experienced by breeders during ovulation can have long term effects on embryo development.

The mean diameter of pollack eggs $(1184 \pm 54 \mu \mathrm{m})$ observed in this study was close to the value reported by Hislop and Bell (1987) in this species $(1160 \mu \mathrm{m})$. As 
recorded in numerous fish species (Brooks et al., 1997), a significant decrease in egg diameter with spawning date was observed in pollack. A similar decrease is especially reported in other Gadoids such as cod (Trippel, 1998) and haddock (Trippel et al., 2000). Similar to observations carried out in wollfish (Tveiten et al., 2001), temperature experienced by pollack breeders during the spawning period had no influence on egg diameter. On the contrary, significant differences were reported in wollfish egg diameter submitted to different temperatures during the vitellogeneis (Tveiten and Johnsen., 1999), suggesting the effect of temperature on yolk deposition during this phase but also the different effects of temperature when applied during different phases of the reproductive cycle. As observed in cod (Ouellet et al, 2001), the diameter decrease of pollack eggs with time was not associated with significant changes of hatching percentage.

In conclusion, temperatures experienced by pollack breeders during the spawning period deeply affect reproduction in terms of number of spawning females, duration of the spawning period, number of spawns collected, total and viable egg output, and hatching and malformation percentages of larvae. The very low spawning performances recorded at $12^{\circ} \mathrm{C}$ suggest that this value is close to the temperature reproduction upper range of pollack. Further investigations are needed to describe physiological mechanims mediating these effects. A better understanding of the effect of temperature on the reproductive function in pollack but also in other fish species would be helpful both for aquaculture and the study of fish recruitment.

\section{References}

Brander, K., 1996. Effects of climate change on cod (Gadus morhua) stocks. In : Wood, 
C.M., Mc Donald, D.G. (Eds.), Global warming : implications for freshwater and marine fish. Cambridge University Press, Cambridge, Soc. Exp. Biol, Sem. Ser. 61, 256-278.

Brooks, S., Tyler, C.R., Sumpter, J.P., 1997. Egg quality in fish: what makes a good egg? Rev. Fish Biol. Fish. 7, 387-416.

Brown, N.P., Bromage, N.R., Shields, R.J. , 1995. The effect of spawning temperature on egg viability in the Atlantic halibut (Hippoglossus hippoglossus). In: Goetz, F.W., Thomas, P. (Eds.), Reproductive Physiology of fish, Proceedings of the Fifth International Symposium, 2-8 July 1995, Austin, Texas, 181.

Buchet, V., Suquet, M., Omnes, M.H., Petton, B., Normant, Y., Severe, A., Quéméner, L., Barone, H., Fauvel, C., Gaignon, J.L., 2002. Pollack (Pollachius pollachius) : Acquisition of biological data in a breeding purpose. In: Seafarming today and tomorrow, Proceedings of Aquaculture Europe 2002, Trieste, Italy, 16-19 October 2002. EAS, Oostende, Sp. Publ. 32, 165-166.

Bye, V.J., 1984. The role of environmental factors in the timing of reproductive cycles. In: Potts, G., Wotton, R. (Eds.), Fish reproduction: Strategies and tactics, Academic Press, London, pp.187-205.

Carillo, M., Zanuy, S., Prat, F., Serrano, R., Bromage, N.R., 1993. Environnemental induction of spawning in seabass. In: Roberts, R.J, Muir, J. (Eds.), Recent advances in aquaculture, Blackwell, Oxford, 4, 43-54.

Fornies, M.A., Mañanos, E., Carillo, M., Rocha, A., Laureau, S., Mylonas, C.C., Zohar, Y., Zanuy, S., 2001. Spawning induction of individual European sea bass females (Dicentrarchus labrax) using different GnRHa-delivery systems. Aquaculture 202, 221-234. 
Fromentin, J.M., Stenseth, N.C., Gjosaeter, J., Johannessen, T., Planque, B., 1998.

Long-term fluctuations in cod and pollack along the Norwegian Skagerrak coast. Mar. Ecol. Prog. Ser. 162, 265-278.

Hislop, J.R.G,. Bell, M.A., 1987. Observations on the size, dry weight and energy content of the eggs of some demersal fish species from British marine waters. J. Fish Biol. 31, 1-20.

Johansen, T., Nyhammer, G., Otterlei, E., Naevdal, G, Brix, O., 1999. Sexual maturation in cod (Gadus morhua L.) in relation to strain, temperature, sex, size and haemoglobin type. In : Norberg, B., Kjesbu, O.S., Taranger, G.L., Andersson, E, Stefansson, S.O. (Eds.), Reproductive Physiology of fish, Proceedings of the Sixth International Symposium, 4-9 July 1999, Bergen, Norway, 343.

Levitus, S., Boyer, T.P., 1994. World ocean atlas. NOAA, USA, Nesdis Atlas 4, 117pp.

Maillard, C., 1986. Atlas hydrologique de l’Atlantique nord-est. Ifremer, Paris, 205pp.

Omnes, M.H., Sévère, A., Barone, H., Suquet, M., Buchet, V., Le Roux, A., Gaignon, J.L., Fostier, A, Fauvel, C., 2002. Growth and reproductive performances of juveniles and sexually mature pollack (Pollachius pollachius) in different conditions. In: Seafarming today and tomorrow, Proceedings of Aquaculture Europe 2002, Trieste, Italy, 16-19 October 2002. EAS, Oostende, Sp. Publ. 32, 394-395.

Ouellet, P., Lambert, Y., Bérubé, I., 2001. Cod egg characteristics and viability in relation to low temperature and maternal nutritional condition. ICES J. Mar. Sci. $58,672-686$.

Pankhurst, N.W., Purser, G.J., Van der Kraak, G., Thomas, P.M., Forteath, G.N.R, 
1996. Effect of holding temperature on ovulation, egg fertility, plasma levels of reproductive hormones and in vitro ovarian steroidogensis in the rainbow trout Oncorhynchus mykiss. Aquaculture 146, 277-290.

Poertner, H.O., Berdal, B., Blust, R., Brix, O., Colosimo, A., Wachter, B., Giuliani, A., Johansen, T., Fischer, T., Knust, R., Lannig, G., Naevdal, G., Nedenes, A. 2001. Climate induced temperature effects on growth performance, fecundity and recruitment in marine fish: developing a hypothesis for cause and effects relationships in Atlantic cod (Gadus morhua) and common eelpout (Zoarces viviparus). Cont. Shelf Res. 21, 1975-1997.

Quéro, J.C. and Vayne, J.J., 1997. Les poissons de mer des pêches françaises. Delachaux and Niestlé, Lausanne, 304pp.

Suquet, M., 2001. Le lieu jaune (Pollachius pollachius): Biologie, pêche, marché et potentiel aquacole. Ifremer, Plouzané, 35pp.

Suquet, M., Petton, B., Normant, Y., Dosdat, A. and Gaignon, J.L., 1996. First rearing attempts in pollack (Pollachius pollachius). Aquat. Living Resour. 9, 103-106.

Taranger, G.L. and Hansen, T., 1993. Ovulation and egg survival following exposure of Atlantic salmon, Salmo salar L., broodstock to different water temperatures. Aquac. Fish. Manage. 24, 151-156.

Trippel, E.A., 1998. Egg size and viability and seasonal offspring production of young Atlantic cod. Trans. Am. Fish. Soc. 127, 339-359.

Trippel, E.A., Castell, J.D., Neil, S.R.E, Blair, T.J., 2000. Assessment of egg quality of haddock (Melanogrammus aeglefinus) in paired matings. In : Norberg, B., Kjesbu, O.S., Taranger, G.L., Andersson, E, Stefansson, S.O. (Eds.), Reproductive Physiology of fish, Proceedings of the Sixth International Symposium, 4-9 July 1999, Bergen, Norway, 405-407. 
Tveiten, H., Johnsen, H.K., 1999. Temperature experienced during vitellogenesis influences maturation and the timing of ovulation in common wollfish. J.Fish Biol. 55, 809-819.

Tveiten, H., Solevag, S.E., Johnsen, H.K., 2001. Holding temperature during the breeding season influences final maturation and egg quality in common wolffish. J. Fish Biol. 58, 374-385.

Van der Kraak, G, Pankhurst, N.W.,1996. Temperature effects on the reproductive performance of fish. In: Wood, C.M., Mc Donald, D.G. (Eds.), Global warming : implications for freshwater and marine fish. Cambridge University Press, Cambridge, Soc. Exp. Biol, Sem. Ser. 61, 159-176.

Van der Meeren, T., Ivannikov, V., 2001. Seasonal shift in spawning of cod broodstocks by light manipulation : egg quality and larval rearing. In :Larvi 2001, Proceedings of the Third Fish and Shellfish Larviculture Symposium, Hendry, C.I., Van Stappen, G.V., Wile, M., Sorgeloos, P. (Eds.), EAS, Oostende, Sp. Publ. 30, 616-617. 
Table 1. Effect of water temperatures on spawn duration and frequency (different letters superscripts indicate significant differencies among means).

\begin{tabular}{|c|c|c|c|c|}
\hline Parameter & $8^{\circ} \mathrm{C}$ & $10^{\circ} \mathrm{C}$ & $12^{\circ} \mathrm{C}$ & $\mathrm{P}$ \\
\hline Duration of the spawning period (days) & $65.3 \pm 0.6^{\mathrm{a}}$ & $42.3 \pm 11.8^{\mathrm{b}}$ & $47.0 \pm 1.4^{b}$ & 0.05 \\
\hline Spawn number & $23.3 \pm 2.5^{\mathrm{a}}$ & $17.3 \pm 10.1^{\mathrm{a}}$ & $3.0 \pm 3.6^{\mathrm{b}}$ & 0.05 \\
\hline Egg number (x10 $\left.{ }^{3} . \mathrm{kg}^{-1} \mathrm{~B} . \mathrm{W}.\right)$ & $599612 \pm 249545^{\mathrm{a}}$ & $323230 \pm 136796^{a}$ & $26068 \pm 35989^{b}$ & 0.01 \\
\hline Viable egg number (x10 $\left.. \mathrm{kg}^{-1} \mathrm{~B} . \mathrm{W}.\right)$ & $192034 \pm 145870^{\mathrm{a}}$ & $56479 \pm 19614^{\mathrm{ab}}$ & $4175 \pm 7167^{\mathrm{b}}$ & 0.05 \\
\hline Fertilization rate (\%) & $28.7 \pm 19.8$ & $16.0 \pm 0.6$ & $7.6 \pm 10.3$ & N.S. \\
\hline Hatching rate (\%) & $35.8 \pm 8.5$ & $9.8 \pm 8.0$ & $*$ & 0.05 \\
\hline Malformation rate (\%) & $7.3 \pm 1.4$ & $2.3 \pm 1.8$ & * & 0.05 \\
\hline
\end{tabular}

* because of the low number of spawn collected at $12^{\circ} \mathrm{C}$, hatching and malformation percentages are only presented for 8 and $10^{\circ} \mathrm{C}$. 
$8^{\circ} \mathrm{C}$
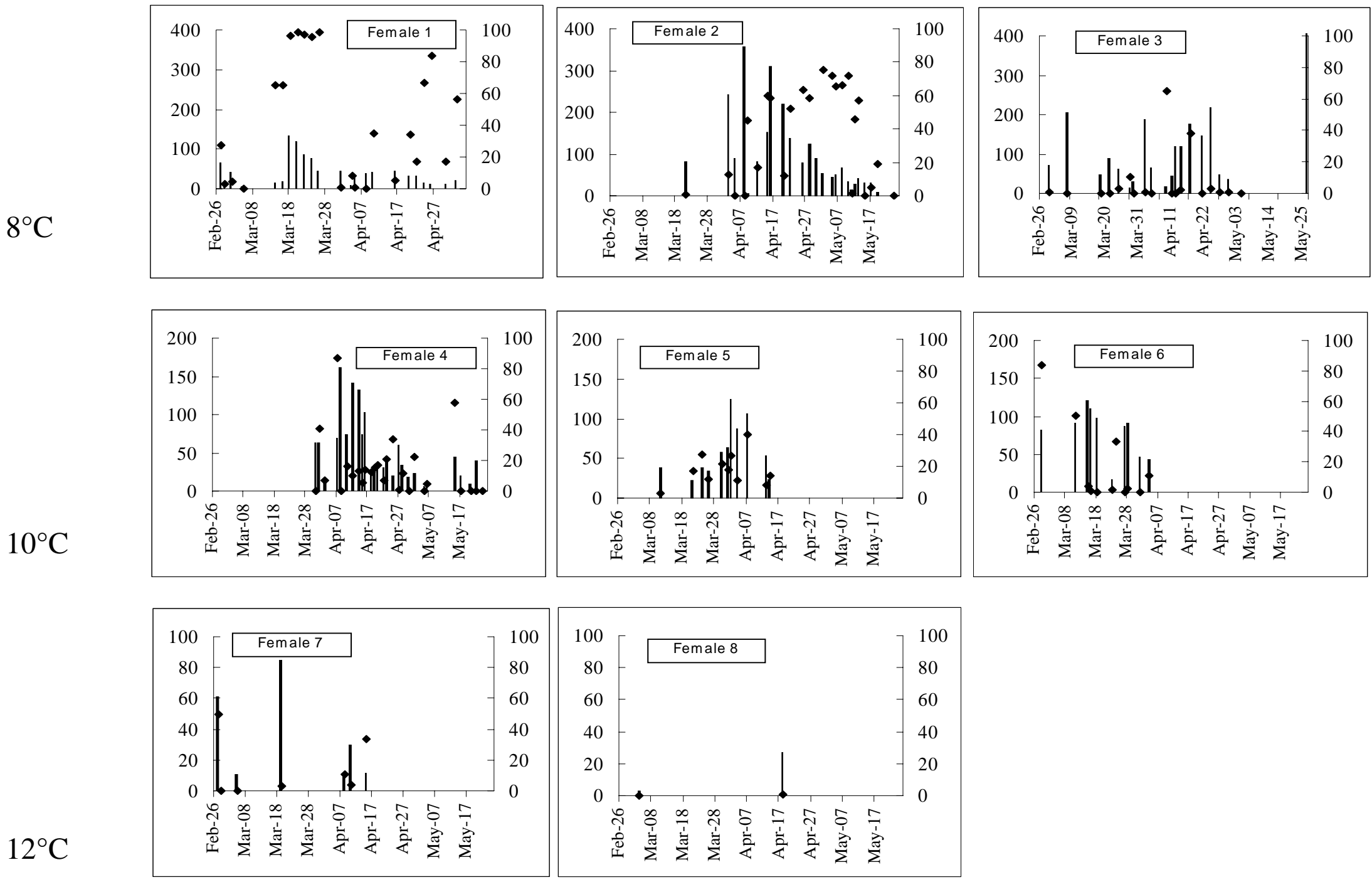

Fig. 1. Changes with time of individual egg production and fertilization percentage in response to exposure to different water temperatures ( :egg number, $\_$: fertilization percentage). 


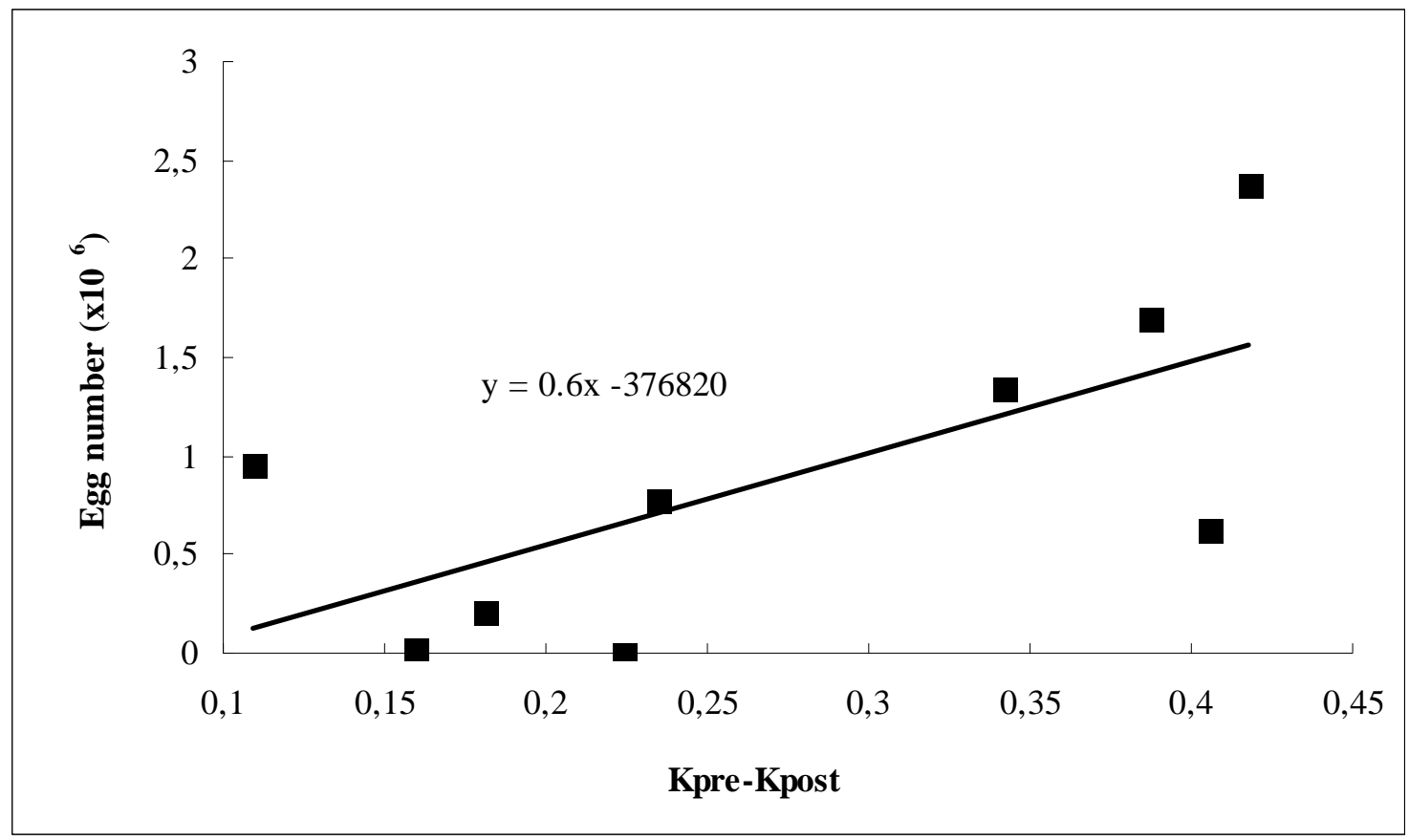

Fig. 2. Relationship between (Kpre-Kpost) and the total number of collected eggs per female (data are pooled from nine females; $\underline{\mathrm{P}}<0.05 ; \underline{\mathrm{r}}^{2}=0.452$ ).

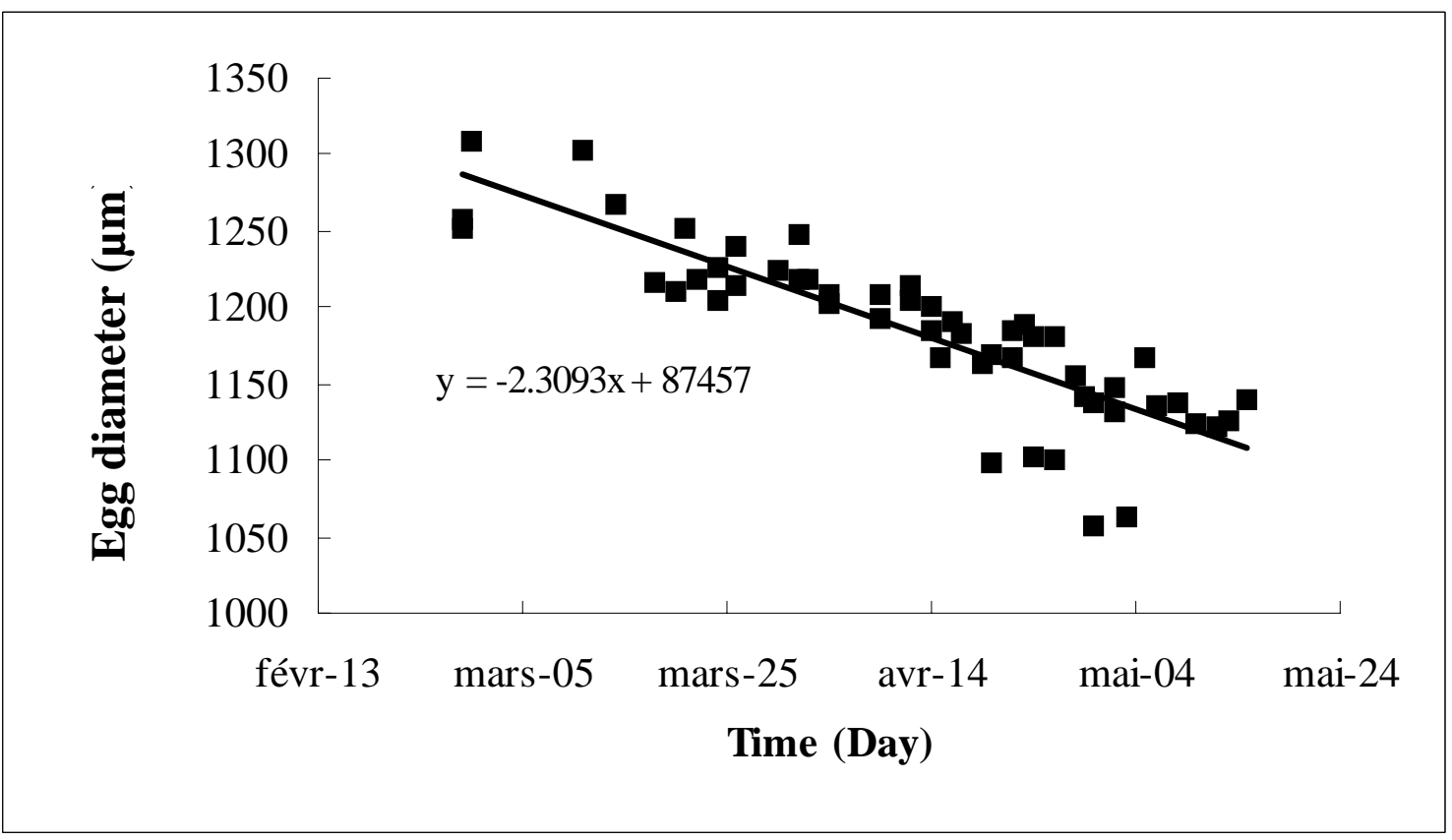

Fig. 3. Changes of viable egg diameter with time (data are pooled from eight spawning females; $\left.\underline{\mathrm{P}}<0.001 ; \underline{\mathrm{r}}^{2}=-0.881\right)$. 